\title{
A CALL FOR A COLLABORATIVE APPROACH TO UNDERSTANDING TEXTUAL COHERENCE IN QURAN"')
}

\author{
Nahla Nadeem ${ }^{1}$
}

\section{ABSTRACT}

Over the years, there has been a considerable debate over textual coherence in Quran and whether or not verses and sections of Quran thematically cohere to make one unified whole as a text. This issue has been thoroughly investigated by early exegetes as well as modern scholars to show how the unique texture of Quran as a genre has contributed to this perceived incoherence. Thus, the paper aims to investigate the reasons behind this perceived incoherence and an explanation of how its unique genre characteristics demand a collaborative approach to finding textual relations among the different sections within and across the Holy text. Drawing on linguistic theories of textual coherence and schemata theory, the researcher developed a collaborative approach to coherence (CAC) upon which she designed an analytical model of investigating textual coherence in Quran. The model comprises two processes: an interpretation process and a reflection process- which cover the different cognitive processes a "critical" reader would go through in order to fully interpret the Quranic text. Through applying the CAC model to Surat AnNaba? (30: 78), the paper investigates both aspects of collaborative coherence: interpretation and reflection as necessary ingredients to perceiving textual relations in Quran. The (CAC) model thus, contributes to the theory of coherence by providing a broader model for the analysis of coherence relations. It also emphasizes the major role played by collaboration and intertextuality in providing textual evidence of the inherent functional links among the different verses and sections so that all parts of Quran are seen to contribute to its overall coherence.

Keywords: Collaborative approach to coherence (CAC), textual analysis, intertextuality, Quran exegesis.

\footnotetext{
() This article was submitted on: 04/02/2015 and accepted for publication on: 17/04/2015.

${ }^{1}$ Cairo University, Applied Linguistics, email: nahlanadeem29@gmail.com
} 


\subsection{INTRODUCTION}

The question of whether or not Quranic surahs exhibit textual coherence has been open to a considerable debate by many Muslim, as well as Western, scholars and they seem to be divided on the matter. A common exegetic practice in interpreting Quran (e.g. Ibn Kathir, among others) is to divide the surah into mini texts for explanation and interpretation. How these mini texts cohere to form a unified whole has been investigated by early exegetes as well as modern scholars e.g. (El Awa, 2006; Mir, 1986; Nisaburi, 1996; Razi, 2011; Robinson, 2003; Zarkashi, 1990) and is still open to investigation. While some scholars conclude that surahs particularly the longer ones lack thematic unity in a way that makes some describe the Quran as "hopelessly disjointed" or "a confused jumble", other scholars investigate thematic and structural unity in Quran and talk about different types of coherence in Quran. In the Islamic literature, early and modern exegetes are quite convinced that although the Quranic surah may contain a wide variety of topics which are not necessarily linearly connected under one unified theme, Quran as discourse offers a unified message through preaching the main principles of Islam to mankind. The present study attempts to answer some of the questions raised around this topic, namely:

1. What are the main reasons behind this perceived incoherence in Quran, if any?

2. How can the Quran be interpreted so that the unique features of the text are taken into account?

3. If finding coherence needs a reader's collaboration in deciphering textual relations in Quran, what are the basic components of such a collaborative approach with an application on surat An_Naba?;

4. And finally, what are the implications for using the collaborative approach to coherence (CAC) in understanding textual relations in Quran?

In the following sections, I will a) review some of the approaches that tackled coherence in Quran; b) discuss some unique genre characteristics in Quran; c) present the $\mathrm{CAC}$ as a comprehensive model in finding unity among the diverse topics tackled in Quran; c) apply the approach to surat An-Naba? (30:78); and d) finally, draw conclusions on the effectiveness of the model in exploring textual coherence in Quran. 


\subsection{Coherence Studies in Quran exegesis: The Main Approaches to the Study of Textual Coherence in Quran}

There are different approaches to the study of textual coherence in Quran. What early exegetes did (e.g. Ibn Kathir, among others) was to divide the surah into chunks of verses and comment on each separately while making connections with other verses that carry more or less similar content. This common exegetic practice of dividing the surah into sections and mini- texts whenever there is a shift of topic was an attempt to interpret the verses as they appear in the present compilation order. This approach has led many Muslim and Western scholars to the belief that the linear connection between the verses is problematic and Quran lacks textual unity as a text. Robinson (2003) writes:

A complaint frequently voiced by English readers of the Quran is that it is hopelessly disjointed, 'a confused jumble' as Thomas Carlyle put it.' Part of the problem is the sudden and unexpected changes in subject matter: stories about Moses, Noah, and other familiar 'biblical' characters are found side by side with graphic descriptions of paradise and hell, instructions and words of comfort addressed to Muhammad and sweeping criticisms of unbelievers. (p.98)

Moreover, the non-linear order of revelations and the compilation process of the verses have often cast doubts and raised a lot of questions about whether or not the text as it stands might have been differently arranged at the time of the Prophet and his companions ${ }^{\text {ii }}$. This has led many Western scholars to question the existing order of the verses while others even attempt to reconstruct it chronologically as it was revealed in an attempt to make sense of the many topics the Quranic surah tackles (See Bell, 1991). Perhaps these attempts to call Quran a non-text or scramble the Quranic text to follow a linear/ chronological order may indeed tell us something about the approaches and the assumptions used in tackling this textual feature in Quran, i.e. that the verses and the surahs must have been differently arranged. What early and modern Muslim scholars did, however is to accept the present order of the surahs and verses through the evidence of authentic hadith ${ }^{\text {iii }}$; yet, attempt to find unity among the different parts of the text so these interconnections become more tangible and quite explicit. These attempts can be summarized as follows:

1- Some exegetes study the circumstances "munasabah" that accompany the revelation of the verses in Quran as recorded and documented in (sunnah) the hadith tradition to make connections and provide a rationale behind the sequence of the verses as they exist in Quran now. Some of the leading scholars in this trend are: Nisaburi (1996), Razi $(Y \cdot 11)$ and Zarkashi (1990). 
2- Other studies examined the sequence of the surahs as they appear in the holy Quran to provide a rationale behind the existing sequence of the surahs and verses. From the early exegetes, there are two leading scholars in this type of tafsir: AlBika'y (885 H.), As-Suyuti (1975) and this approach has been later developed in "Farahi- Islahi's theory of nazm (patterns) in Quran” (in Mir, 1986).

3- A third approach is a synthesizing approach through which exegetes study common topics that are tackled in different surahs of Quran. Rather than explaining the rationale behind the linear sequence which Western scholars find problematic, this approach depends on synthesizing themes based on logical rather than chronological order (e.g. verses that tackle issues relating to the family, divorce, war and jihad, Islamic law...etc. are compiled under themes in order to clarify the overall purposes of Quran ${ }^{\text {iv }}$. Fazulur Rahman (2009) identifies six major themes in Quran around which all Quranic verses revolve. In his introduction to his book Major Themes of the Quran, he (2009) wrote:

I am convinced that this synthetic exposition is the only way to give a reader a genuine taste of the Qur'ann, the Command of God for man. Even if the chronological order could be feasibly reconstructed passage by passage (which I consider a real impossibility_ pace Richard Bell!), it would only explicate what is germinal in the original, master idea. This is radically different from the "dissective study" approachchronological or other-whose usefulness for scholarship is obvious but which must disclaim any pretensions to treat the Qur'ān as what it claims to be: God's message to man. (p. v)

However, the common view about the Quran particularly for Western readers has been that it is lacking coherent composition as a text. Two significant works in the literature that are particularly important for the purpose of the present study are El Awa (2006) and Farahi- Islahi's Nazm theory (as quoted in Mir, 1986). They both attempt to address the issue of coherence in Quran: while El Awa's approach is based on modern linguistic/ pragmatic theory mainly the relevance theory (RT) of Sperber \& Wilson (1989) to prove it, Islahi, in his "Tadabbur-i- Quran"/ "Reflection on Quran", however, adopts a more traditional exegetical approach following his mentor Farahi's "Nazm theory" i.e. proving through analysis and closer investigation the linear connection that exists between the Quranic verses, surahs or both. ${ }^{v}$. In the present study, I will use both as reference since like El Awa, the proposed model is based on modern linguistic 
theories of textual coherence as well as drawing on the very rich literature of Quran exegesis.

So far, I have offered an overview of some of the most influential approaches in investigating coherence in Quran. In the next section, I will focus on Quran as a unique type of text then tackle some of the modern linguistic approaches to the study of coherence mainly (Halliday \& Hasan, 1976; Reckheit et al. 2011; Reinhart 1980; Tanskanen, 2006).

\section{QURAN AS A UNIQUE GENRE: SEEKING UNITY IN DIVERSITY:}

Knowledge about genre characteristics is essential for interpreting texts. Quran as a unique type of text and its rhetorical structure are important aspects that need to be considered in interpreting it. Having said this, there are two main factors that cause the problem of not perceiving textual connectedness in Quran for nonMuslims: one lies within the text; i.e. the way the text is uniquely composed and the other is in the interpretation process itself. Quoting El Awa, Quran exhibits two unique textual features: a) the proverbial nature of the verse as the basic unit of meaning and analysis and b) the indeterminacy of the connections between the surahs or the verses through the use of loose connectives or a rhetorical device called "iltifat"vi. El Awa writes (2006):

In long Arabic text-tradition it is considered to be good style when sentences are proverbial, because that makes them quotable and easy to remember and to integrate in other contexts. One means of achieving this stylistic feature is to limit one's use of speech connectives. That is, the less connectives there are, the less restricted the text is to its particular context, and the more likely it is to apply to other situations without needing to modify its language or paraphrase it. Another means of achieving proverbiality of language is the use of homonyms and grammatical structures, which allow for multiplicity of meaning. The Quranic utterance being a classical literary text reflects these features extensively. The impact of this on the Quranic sentences is that they contain a minimum of inter-sentence connectives and their meanings are layered and very generalized and can in many cases be applied to an unlimited number of situations. (p.47)

El Awa (2006) has also referred to another textual feature which leads to this problem of the lack of connectedness and consistency particularly to a Western reader, i.e. the indeterminacy of textual relations in Quran. This textual feature in particular is what causes problems in assigning definite textual relations to mark the linear connections among the verses. El Awa (2006) states that there are major themes that the Quran generally tackles but the way they are presented 
is largely unconstrained and diverse particularly in longer surahs. Unlike for example, legal language where textual relations are explicitly stated so meaning relations are set in one clear direction, this indeterminacy of textual relations in Quran marks the text as open to different interpretation and very rich in making textual connections but not necessarily incoherent. (P. 34)

She also commented on the extensive use of "iltifat" as a rhetorical device in Quran. Often times, there is a pronoun shift within or across verses to mark a change of focus or addressee. These unique textual features, among others, open new possibilities of interpretation whether the verse is quoted alone or in connection with other verses across the Quranic text. That explains why early, modern and even common readers of Quran often quote the verse in isolation or in context (i.e. in the context of the verses that precede it or follow it or in connection with other verses that have more or less similar content). In other words, textual relations are and can be sought through the linear order of the verses or in the wider context in which they occur. In my opinion, this has affected textual relations in Quran exegesis in two ways: 1) the perception of the verse as a stand-alone unit of meaning that can be quoted by itself and not necessarily in its immediate context and b) that intertextual links among the verses extend beyond the linear order to cover verses that might occur in other surahs, as well. This is validated through the basic exegetic concept that القران "يفسر بعضه بعضا" "Quran explains itself" and the heavy cross referencing in early exegetic works. Thus, instead of focusing only on the linear connections between individual verses or surahs and finding it lacking coherence in this sense, textual relations in Quran can in fact be sought on a verse-level, across surahs and through thematic interconnections across Quran.

Given these two factors, finding coherence among the different verses or sections and across the different surahs relies mainly on the interpretation process itself. Therefore, I argue that exploring textual relations in Quran as such is a reader- oriented process that mainly depends on collaboration and intertextuality where the reader of Quran attempts to make connections within and across the surahs. This process is marked by a great deal of collaboration to find textual unity among the diverse topics Quran tackles in the one surah. This view of textual relations, as opposed to the old thematic unity or linear connectivity approaches demands a review of the coherence models available which is what I will attempt to do in the following section in order to introduce the proposed collaborative model of coherence: a model that could account for these multiple possibilities of interpreting Quranic verses and as such could have a great influence on our understanding of the texture of Quranic discourse. In what follows, I will briefly overview the available coherence models to present my own 
collaborative model of coherence that covers the gap found in the literature and could better present textual relations in Quran.

\section{DESIGNING THE "COLLABORATIVE APPROACH TO COHERENCE” MODEL:}

Since Halliday \& Hasan's introduction of the concept of textual coherence (1976), there have been different approaches to explain the concept. Primarily, studying coherence has been closely linked to the study of cohesion; the study of the semantic relations between propositions within the text using cohesive devices as clues. As such, coherence is manifested through the formal devices used on the surface which signal the meaning connections within the text. Reinhart (1980) postulates three conditions in order for the text to be coherent:

1- Connectedness which covers the linear connections of sentences in a text.

2- Consistency which is a semantic condition requiring each sentence to be logically consistent with the previous and following one.

3- Relevance as a pragmatic condition that covers the relation between the sentence and the overall theme as well as the context it occurs in.

Recently, however, schemata and reader- response theories have added a new dimension to the study of textual coherence. The two theories adopt the view that coherence resides not in the text itself, but is rather the outcome of a dialogue between the text and its reader in which the above conditions play a key role. It views coherence not as a formal property of the text per se, but as a discourse processing concept which is cognitive in nature ${ }^{\mathrm{vii}}$. Blum Kulka (cited in Venuti, 2000, p. 298) states that coherence can be viewed as a covert potential meaning relationship among parts of a text, made overt by the reader through a process of interpretation. It is a collaborative process in the sense that readers develop a coherent interpretation of text through an interactive process of "combining textual information with the information a reader brings to a text" (Grabe, 1988, p.56 quoting Widdowson, 1979) and this is the view adopted in the present study. He writes (1988):

In this view the reading process is not simply a matter of extracting information from the text. Rather, it is one in which the reading activates a range of knowledge in the reader's mind that he or she uses, and, in turn may be refined and extended by the new information supplied by the text. Reading is thus viewed as a kind of dialogue between the reader and the text. (p.56) 
Successful interpretation thus involves both the text itself and the knowledge the receiver brings into it (Lundquist 1989; Shiro 1994; Van de Velde 1985, 1989); i.e., establishing a dialogue with the text that guarantees the processing of coherent information-flow. Let us close this point with a quotation from Linell (1998):

The production of meaning takes place in interactions, ... in the reader's efforts in assigning meaning to the text and in using the text as a vehicle, as a means of activating semantic potentials of words and text chunks, in the service of creating an understanding which somehow fits the contexts given and the purposes which are relevant for him. (p. 268)

This collaborative sense of coherence is particularly necessary when textual relations - as stated above- are left unconstrained so as to allow for a variety of interpretations and interconnections not just on a linear level but across the Holy text. Intertextuality is one of the unique features of Quran where all verses contain traces of other verses under the same theme, and often they cannot

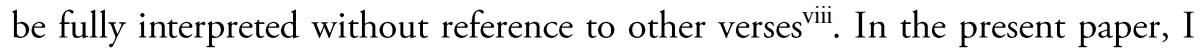
attempt to present a model of interpretation that reflects this collaborative approach to textual coherence (CAC) in Quran. The model comprises two processes: an interpretation process and a reflection process of making connections while interpreting Quran (see figure 1 below)

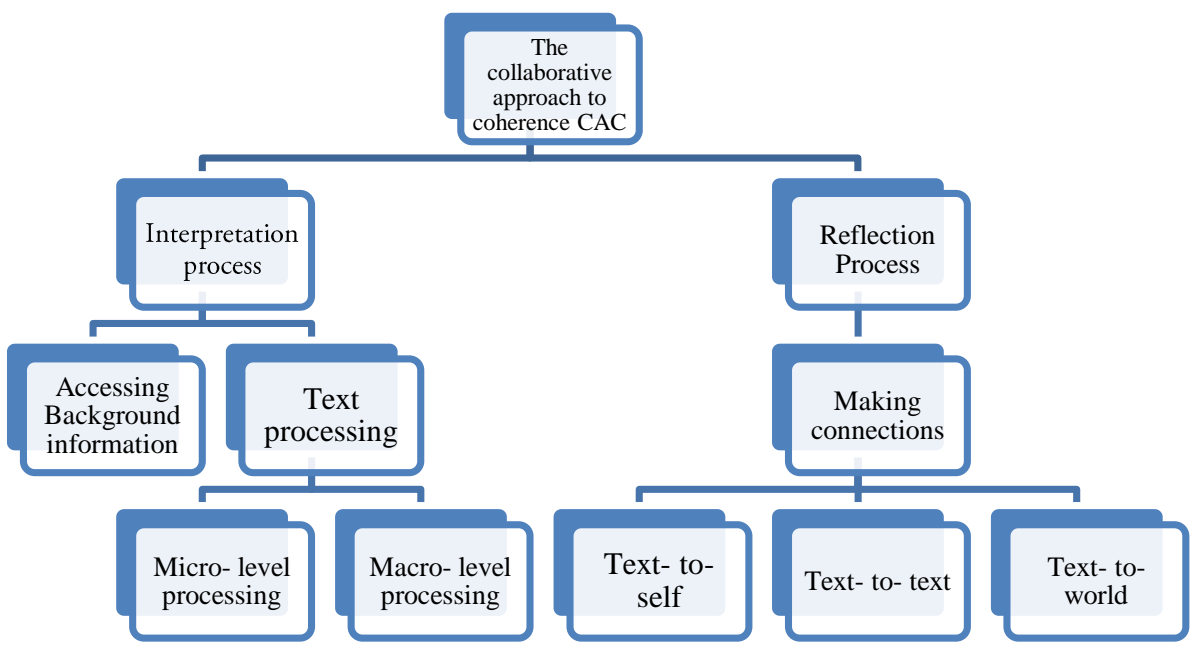

Figure 1: The proposed model of the collaborative approach of textual coherence in Quran

The proposed model divides the collaborative approach to coherence into two parallel processes. As shown in the model above, there are two factors that get into the interpretation process: having the necessary background 
knowledge that provides a frame for interpretation (e.g. knowledge of genre, examining the title to get the overarching theme that holds the different parts of the text together if applicable, and the circumstances in which the surah was revealed). The text processing stage then occurs on two levels: a micro level which covers the ability to assign a unifying theme that sets a frame for interpretation ${ }^{\text {ix }}$ and accessing the semantic propositions through knowledge of vocabulary and grammar. At this level, it will suffice to get a basic summary of the surah content which paves the way for a more in-depth textual coherence analysis in the next level. At the macro- level of analysis, the reader mainly investigates the themes, sub-themes and how they relate to the division of the surah into sections and mini texts. Features of the text's cohesive profile is also examined and further investigated to confirm the meaning connections among the different parts of the text. Only then can a reader reach a full interpretation of the text.

However, along with the interpretation process outlined above, the reader also goes through a reflection process of making connections between the text and self, text, text to text and to the world. Taking the verse as the basic unit of meaning, readers of Quran often reflect on the verse as it connects to their lives, other verses in the same surah or across the Holy text. Readers of Quran often find a lot of applications of the verse that relate to current events and the world at large. This reflection process usually happens either simultaneously while reading or after the basic processing of the propositions within the text so that new connections can be made and more textual relations can be perceived. It follows that the level of interpretation may differ according to the reader's ability in deciphering text meaning/s and making connections.

Having thus outlined the proposed approach to textual coherence in Quran, below are more details of how the model can be applied to account for both aspects of the text processing approach to coherence: the interpretation process and the reflection process.

\section{The interpretation process that comprises two stages:} Accessing background knowledge includes:

1) Knowledge of Quran as a genre and this includes knowledge of whether the surah is Meccan or Madinan and the main features of each type, besides examining the Prophet's authentic sayings that were cited in relation to this particular surah/ verse.

2) The circumstances - "munasaba"- in which the surah/ verses were revealed. 


\section{Text processing involves:}

1) A micro- level interpretation of the surah through:

- Setting a frame and theme for the interpretation of the surah and;

- Accessing the semantic propositions through the knowledge of grammar and vocabulary that enable the reader to arrive at a basic summary of the content of the surah.

2) A macro- level analysis (through in- depth investigation of the theme and text organization):

- This level of analysis covers the problematic area of a) recognizing the overarching topic of the surah and how the different sections relate to one another thematically and $\mathrm{b}$ ) examining the cohesive links among the different parts. Here, the pragmatic function of the verses is also examined to shed light on implicit links among the different units of analysis whether the verse or the section. It will be presented graphically in figure 2 below (see P. 15).

2. The reflection process involves the process of making connections ${ }^{\mathrm{x}}$ which can be summarized as follows:

A- Text-to-self:

How does this relate to my life?

What does this remind me of in my life?

What were my feelings when I read this?

B- Text-to-text:

How is this verse similar to other verses I've read?

How does the verse relate to authentic hadith?

How is this different from other verses I've read?

How does this verse relate to pre-Islamic literature particularly preIslamic poetry ${ }^{\mathrm{xi}}$ ?

C- Text-to-world:

What does this remind me of in the real world?

How is this text similar to things that happen in the real world?

How is it different from things that happen in the real world?

How did this part relate to the time of the Prophet and Islamic history? (Adapted from Keene and Zimmerman (1997).

Having thus built a model for the analysis of textual relations in Quran, what remains is to apply the model proposed to surat An-Naba?. 


\section{THE ANALYSIS OF SURAT AL-NABA' (CHAPTER 30:78) ${ }^{\mathrm{xii}}$ : 4.1.Background}

Being a Meccan surah sets expectations about the topics and themes tackled. One of the principal topics in the Meccan period surahs is providing logical evidence of the occurrence of the Day of Judgment through evidences of God's creation and lessons from history or both. This was an essential stage for building faith for the early Muslims, answering the non- believers' doubts of the hereafter and setting the Islamic worldview of why Man was created and his Mission on earth. At the time, Prophet Muhammed (PBUH) was frequently troubled with the nonbelievers' disbelief in the Day of Judgment and their denial of its occurrence. They find it very hard to believe that after Man turns into dust, God can bring him back for a Day of final judgment. They kept sarcastically asking him: "when will it happen if ever?" Revelation thus offers a reply and a confirmation of its occurrence through providing logical evidences from natural phenomena. The miracle of the creation of the natural phenomena are, thus, quoted as proofs of God's power and supremacy over all creatures. The surah starts with a rhetorical question that directly addresses the non- believers' questions and doubts to start a series of evidences of its inevitable occurrence: a persuasive technique that matches Robert Browning's famous quote: "I show you doubt, to prove that faith exists".

\subsection{Text Analysis:}

The assertion of the occurrence of Doom's Day and a description of what will happen on that day. The title, here gives a hint of what the surah is about since "the tidings" covers passing news about the joy and agony of the day for all parties concerned: believers and otherwise.

Having just set the frame for interpretation, the different sections of the surah that might be claimed to represent shifts in topic immediately follow the main thread that binds them together. There are at least 6 sub- sections in the surah: each tackling one aspect of the theme. Section one (verses 1-5) starts with a rhetorical question that states the disbelievers' doubts about the Day of Judgment and a confirmation of its occurrence. Section two (verses 6-16) provides an extended reply in the form of giving the reader a series of proofs taken from natural phenomena: e.g. the creation of the earth, mountains, and Man; the miracle of day and night and along with it sleep and rise, the creation of the sky, the making of rain that is the main source of plantation and vegetation on earth.

These undoubted natural evidences of God's absolute power in His creation, thus, culminate in the final assertion of the occurrence of the final Day of Judgment. Section three (verses 17-36) then offers a description of the horrors 
of the Day with two sub-sections (4-5); one giving details of hell fire and its residents while the other gives details of the beauty and blessings the believers will have in paradise. Hell fire and/or paradise, here, represent the final destination of Mankind based upon their actions in this life. The three sections together cover verses 17-36. The final conclusion in section 6 (verses 37-40) comes in the form of a reiteration asserting God's supreme power, another brief description of the Day of Judgment and a final warning to mankind stressing the fact that it is drawing near.

\subsection{The Macro- Level Analysis:}

Moving a step further to consider the pragmatic function of the verses, the surah starts with a rhetorical question stating the non-believers' doubts about the Day of Judgment which are answered by a strong confirmation of its occurrence and a series of counter questions that provide undoubted evidences of God's unlimited power and supremacy over all creation (see figure 2 below). The evidences used to prove the occurrence of the Day of Judgment are all taken from the natural phenomena the non- believers see around them so they could be a proof enough. This is followed by another forceful confirmation of the occurrence of the Day (verse 17) and a description of what will happen then (1720). In the hereafter, Quran usually divides people into two categories: the believers and non-believers so each group is talked about in a separate section; those who deserve hellfire and those who will settle in heaven. These sections are often juxtaposed to offer good tidings to the believers and a harsh threat to the non-believers. The surah, then, ends with a wrap up description of the horrors of the Day of Judgment and God's exalted power (verses 37-40) as a final warning and a forceful threat to the non- believers. In fact, verse 17 works so well in connecting the first set where a premise is posed (verses 1- 5) then proofs are sought (verses 6-16) and a final conclusion is drawn which paves the way for the detailed description of the hereafter and the destiny of mankind in each case: believers or otherwise (verse 17-30); then a final note on God's supreme power over all creatures and a final threat to the non-believers. Thus, the meaning and order of the verses are logical as they stand; and they mainly function as a reassurance to the Prophet and the early Muslims, a harsh reply to the unbelievers' doubts and a warning of what is to come.

Through reading the surah carefully, we realize that the slight shift in topic in each sub-section is usually marked by shifts in syntactic or other linguistic/ cohesive devices.

So far, the logical link between the different sections is not problematic at all and all the parts fit together in one unified whole. A final note should be 
made about the distribution of the verses in each section and the cohesive devices used to signal coherence in the text. By far, the longest sections are those devoted to the logical proofs of the occurrence of Doom's Day ( section 2: 11 verses) and the description of Hell fire and some of the attributes of the non- believers (section 4: 9 verses). The two sections, thus, set the tone of the whole surah as both persuasive and threatening. As noted earlier, each section is marked with a topic-shift cohesive signal that not only sets the sub- sections apart from those preceding and following but in some cases help connect some parts together to make one unified whole (e.g. section 4, $5 \& 6$ have the same initial emphatic particle "inna"/ "verily" to denote the thematic link across the three sections). Moreover, the rhyme in verse endings might be another indication of a functional link, e.g. section 1 is set apart from the rest of the surah through a different rhyme to mark the difference in content between stating the unbelievers' doubts and providing proofs. Some cohesive devices are also used to mark the connection within the same section: e.g. in section one, the rhetorical question extends over three verses which are syntactically connected through a modifying prepositional phrase, then a subordinate clause to give further details about the great news the non- believers doubt e.g.:

Table 1: Cohesive markers in Section one

\begin{tabular}{|l|l|}
\hline Verse & $\begin{array}{l}\text { Cohesive markers used within the } \\
\text { section }\end{array}$ \\
\hline What are they asking about? Verse 1 & $\begin{array}{l}\text { A rhetorical question that extends } \\
\text { over three verses }\end{array}$ \\
\hline About the great news? Verse 2 & $\begin{array}{l}\text { A modifying Prepositional phrase } \\
\text { and the repetition of "about" }\end{array}$ \\
\hline About which they are in disagreement? Verse 3 & $\begin{array}{l}\text { A modifying subordinate clause \& } \\
\text { repetition of "about" }\end{array}$ \\
\hline Nay they will come to know, verse 4 & $\begin{array}{l}\text { A forceful reply through the use of } \\
\text { "Nay" }\end{array}$ \\
\hline Nay, again, they will come to know. Verse 5 & $\begin{array}{l}\text { A repetition of the verse with more } \\
\text { emphasis through the use of "again" }\end{array}$ \\
\hline
\end{tabular}

The textual analysis, thus, shows that the connection between the sections is not only logical and straightforward but is also made explicit through the cohesive devices used across the text. To illustrate this, the organizational structure of the surah in terms of form, content and function can be graphically represented as follows (see figure 2 below): 


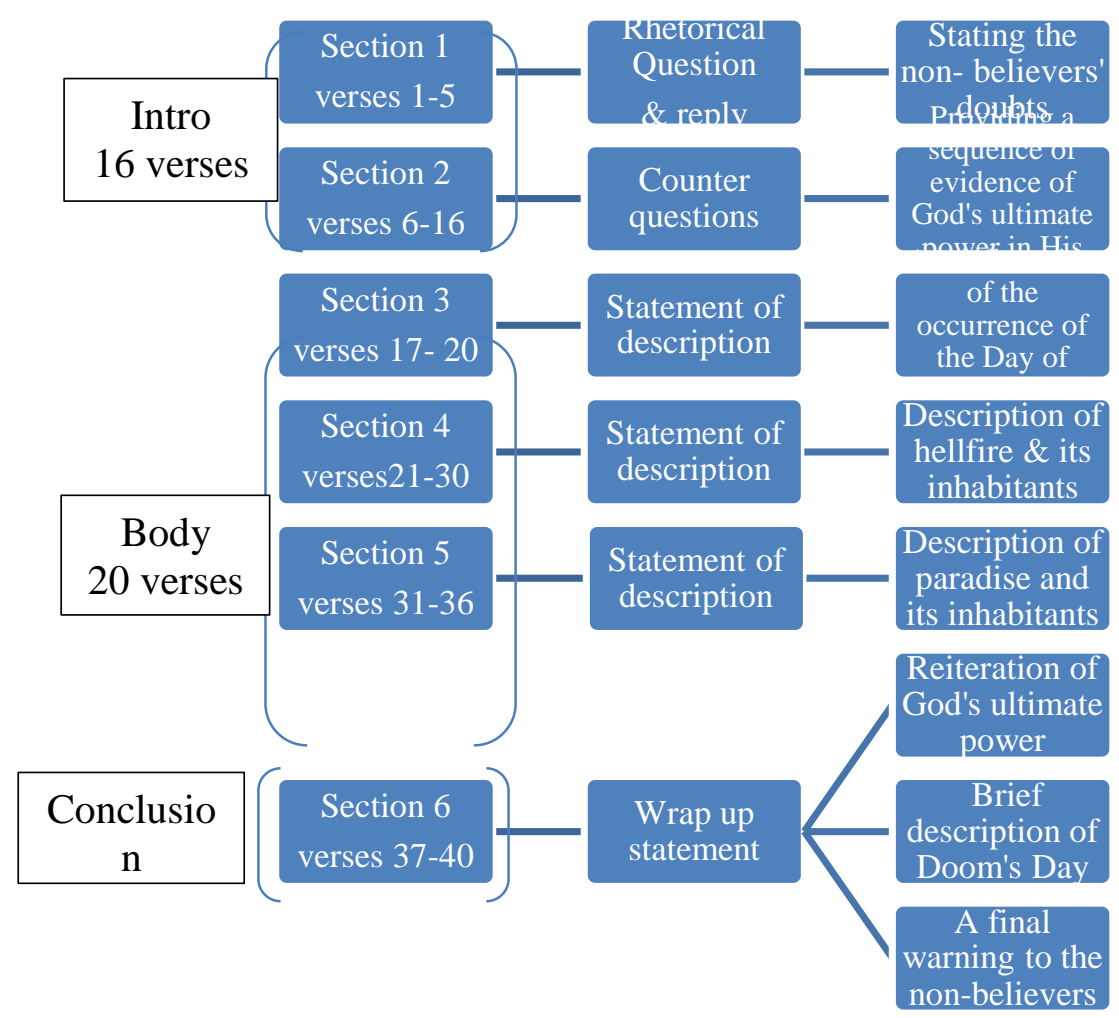

Figure 2: A graphic representation of the organizational structure of the surah

\subsection{The Reflection Process: The Importance of Making Connections:}

Thus far, the model has offered an interpretation of the textual relations among the different sections within the surah; yet, to explore textual relations further, the Quran as a text invites the reader to adopt a collaborative approach rather than just an analytic/ interpretive approach though the latter is extremely important as a start. It invites the readers to make connections between text and self, text and text and text and the world so that new connections can be made and more textual relations can be perceived. Only through reflection can Quran become relevant to a contemporary reader. On a personal level, e.g. the surah might arouse feelings of awe and a sense of refrain from wrong-doing. It can also be an answer to many of the contemporary doubts one might experience concerning the possibility of the hereafter or even a reply to the unbelievers in every age who cast their doubts about the existence of the Day of Judgment. This does not necessarily mean that the proofs given should be convincing to those but at least this is one of the arguments Quran offers in answering these doubts and claims. Including what is called "خواطر حول الأيات و السور" / "personal reflections on the Qur'anic verses and surahs" is a very rich source of 
personalizing the Quran. It offers real life applications to the verses as it makes them personally relevant.

Equally important is the investigation of the intertextual links and cross references that give Quran its unique texture. As mentioned above, the synthetic approach to reading and interpreting Quran is crucial for a full understanding of its message. The main themes of Quran can only be fully investigated and appreciated through intertextuality. Through the investigation of themes across the surahs, there will be perceived patterns that contribute a great deal to providing textual relations among the different surahs and/ or sections in surahs that might look at first sight unconnected or incoherent. As such, a single verse or even a section is open to a wide range of meaning connections that are only possible if we consider those intertextual links. For example, there is a recurring pattern of providing logical evidence of the hereafter and God's ability to resurrect the dead through citing proofs from God's creation and natural phenomena. For example, surat Al Naml (verses 60 - 66) echo the same persuasive pattern. Even on a verse level, the content of verse is often echoed in other surahs and in different contexts that can be intertexually connected and provide textual relations on a wider scale. For example, verse 17 is echoed in another verse in surat $\mathrm{Hud}$ :

Verily, the Day of Decision is a fixed time (Surah 78: verse 17)

And We delay it only for a term fixed. (Surah 11: verse 104)

In this way, the verse - though can be quoted as a unit by itself- must be seen as part of a network of themes and topics that the Quran deals with. Thus, through the major themes that hold together all the different verses/ surahs, one could see a whole new possibility of meanings and meaning connections within and across the Holy Quran.

\section{DISCUSSION AND CONCLUSION:}

So far, the study has offered an overview of the reasons behind the perceived incoherence in Quran and an explanation of how its genre characteristics have contributed to the matter in order to point out the need for the collaborative approach to coherence outlined in the analysis section above. What remains is to discuss the implications for applying the $\mathrm{CAC}$ in coherence studies in general and in understanding textual relations in Quran in particular. I will be looking into two types of contributions: first, how the (CAC) model contributes to the theory of coherence by providing a broader model for the analysis of coherence relations: one that incorporates the semantic propositions expressed, their pragmatic functions and intertextual links. The model combines the schemata and reader response theories with those of textual coherence in an attempt to explain textual relations in Quran. The model as such emphasizes the reader's collaborative role 
in providing textual evidence of the inherent functional links among the different verses and sections so that all parts of the text are seen to contribute to its overall coherence.

The CAC model, thus, sheds light on the major role played by collaboration and intertextuality in interpreting Quran. It emphasizes the reader's role in deciphering textual relations in Quran. The second contribution of the model is how the two-level text processing analysis can offer insights into the interconnections between the different units of the analysis: the verse, the section, the surah and the Quran as a whole. Hence, it explains how the verse as a smaller unit contributes to the sections within the surah and how the verses carry references to other verses and carry additional meanings every time they combine with others. It also takes into account the textual devices for marking coherence across the different sections so that form, content and function are seen as one unified whole.

Through the analysis, the model has helped to uncover not only the relations between the sections but the major role the cohesive devices play in indicating these relations. For example, the emphatic "inna"/ "verily" is used at the beginning of sections $4,5 \& 6$ to set them apart structurally, yet, works as a cohesive device to mark the thematic link as sub-themes. A description of these cohesive ties can, thus, direct our understanding of the relations between parts of the text as they contribute to the analysis of thematic links and the overall text organization. However, cohesive devices are not the only way meaning connections can be explained.

Through the reflection process, the model invites readers to look both within the text and outside it to create text meanings that can be peculiar to every reader according to his/ her ability to connect with the text. If we overview the studies of coherence in Quran, we discover that they miss out on the most important aspect of any reading experience; i.e. the relevance of the text to the reader. Focusing too much on the coherence of the text parts while losing sight of how the reader makes sense of these parts is not enough for a comprehensive study of coherence and textual relations in Quran. The model, thus, helps to explain how the surah as a text though unique in its texture can still make perfect sense to its readers. Through the reflection process, the reader engages in a process of making connections between self and text, text and text and text and the world so that the verse/surah can be relevant to the contemporary reader in his/ her very particular context. After all, what Quran as a message of God aims to do is to change the reader's perception of the world and him/ herself in order to affect his/ her spiritual and ethical well-being. If this is not achieved, even an in-depth reading of the Holy book through the analysis and interpretation of the text does not help much with achieving this end. 
Finally, the approach is detailed enough as it combines the use of some early exegetic practices that are often essential for the interpretation of textual relations among verses/ surahs (e.g. providing the necessary background information what is known as علم المناسبة "munasaba"/ "knowledge of the circumstances in which the verse/surah was revealed" and the use of modern linguistic theories of textual coherence. Thus, it makes use of the rich literature of Quran exegesis and modern linguistic tools of analysis in an attempt to provide the modern reader with a better view of the Quranic message and the Islamic world view.

\subsection{REFERENCES}

Al-Baqa'i, I. U. (n.d). Nazm al-Durar fi Tanasub al-Ayat wa al-Suwar. Cairo : Dar al-Kitab al-Islami.

Al-Ghazali, M. (2005). Nahwa Tafsir Mawdu'i li Suwar al-Quran al-Karim. Cairo : Dar al-Shuruq, 7 th edn.

Al-Naisaburi. H. m. (1966). Ghara'ib al-Quran wa Ragha'ib al-Furqan. Tahqiq: Zakariyy Umairan. Beirut: Dar al-Kutub al-'Ilmiyyah, $1^{\text {st }}$ edn.

Al-Razi, F. (2011). Al-Tafsir al-Kabir. Cairo: al-Matba'ah al-bahiyyah alMisriyyah, $1^{\text {st }}$ edn.

Al-Suyuti. J. A. (1975). Al-Itqan fi 'ulum al-Quran. Tahqiq: Muhammad Abu al-Fadl Ibrahim. Cairo: al-Hai'ah al-'ammah li al-Kitab.

Al-Suyuti. J. A. (1986). Tanasuq al-Durar fi Tanasub al-Suwar.Taqiq: Abdulqadir Ahmad 'Ata. Cairo: Dar al-Kutub al-'Ilmiyyah.

Al-Zarkashi, B. M. (1990). Al-Burhan fi 'Ulum al-Quran. Cairo: Dar alMa'rifah.

Attwood, T. (1998). Asperger's syndrome: A guide for parents and professionals. Jessica Kingsley Pub.

Bell, R. (1991). A Commentary on the Qur'an. Manchester: University of Manchester.

Blum- Kulka, Sh. (2002). Shifts of Cohesion and Coherence in Translation. In L. Venuti (Ed.), The Translation Studies Reader (pp. 298- 313). USA \& Canada: Routledge.

El Awa, S. (2006). Textual Relations in the Qur'an: Relevance, Coherence and Structure. London \& New York: Routledge.

Fazulur Rahman. (2009). Major Themes of The Qur'an (2 $2^{\text {nd }}$ edition). Chicago: University of Chicago Press.

Grabe, W. (1988). Reassessing the Term 'Interactive. In P. Carrell, J. Devine, and D. Eskey, (Eds.), Interactive Approaches to Second Language Reading. Cambridge: CUP. 
Halliday, M. A. K. \& Hasan, R. (1976). Cohesion in English. London: Longman.

Hawwa, S. (1989). Al-'Asas fi al-tafsir. Cairo: Dar al-Salamah. $1^{\text {st }}$ edn.

Ibn Kathir. (n.d). Tafsir Ibn Kathir. http://www.quran4u.com/Tafsir\%20Ibn\%20Kathir/078\%20Naba.htm (Retrieved on 2/11/2013)

Keene, E. \& Zimmerman, S. (1997). Mosaic of Thought. Portsmouth, NH: Heinemann.

Linell, P. (1998). Approaching Dialogue: Talk. Interaction and Contexts in Dialogical

Lundquist, L. (1989). Coherence in scientific texts. In W. Heydrich, F. Neubauer, J. S.

Mir, M. (1986). Coherence in the Quran: A Study of Islahi's Concept of Nazm in Tadabbur-i-Qur'n. Indianapolis, IN: American Trust Publications.

Perspectives. Amsterdam \& Philadelphia: John Benjamins.

Petöfi, \& E. Sözer (Eds.), Connexity and Coherence: Analysis of Text and Discourse (pp. 122-149). Berlin \& New York:Walter de Gruyter.

Reinhart, T. (1980) Conditions for Text Coherence. Poetics Today, 1, 161- 180

Robinson, N. (2003). Discovering the Qur'an: A Contemporary Approach to a Veiled Text. UK: SCM Press.

Shiro, M. (1994). Inferences in text production. In M. Coulthard (Ed.), Advances in Written Text Analysis (pp. 167-178). London: Routledge.

Sperber \& Wilson. (1986/1995). Relevance: Communication and Cognition. Oxford: Blackwell.

Tanskanen, Sanna-Kaisa (2006). Collaborating Towards Coherence: Lexical cohesion in English Discourse. Amsterdam/Philadelphia: John Benjamins Publishing Company.

Van de Velde, R. G. (1985). Inferences and coherence in text interpretation. In E. Sözer (Ed.), Text Connexity, Text Coherence: Aspects, Methods, Results (pp. 261-298). Hamburg: Helmut Buske.

Van de Velde, R. G. (1989). Man, verbal text, inferencing, and coherence. In W. Heydrich,F. Neubauer, J. S. Petöfi, \& E. Sözer (Eds.), Connexity and Coherence: Analysis of Text and Discourse (pp. 174-214). Berlin \& New York:Walter de Gruyter. 


\subsection{Notes}

i See Robinson (2003: 98)

ii The Quran was revealed on different occasions, then combined into surahs upon Prophet Mohammed's instructions not according to chronological considerations.

iii Most Muslim scholars agree that the Prophet (PBUH) himself supervised the compilation process and the order of the surahs and verses as we see them today have reached us through Sunnah mutawwatirah (authentic and valid hadith that is transmitted widely through unbroken chains of narrators) so the present order is considered revelation and beyond doubt. It is widely believed that there is a special wisdom in the present organization of the Quran regardless of the times and occasions of revelation.

$$
\begin{aligned}
& \text { ivمن هؤلاء المفسرين: الزخشري في(الكشاف)، والرازي في(مفاتيح الغييب) ، وسعيد حوى في (الأساس في التفسير)، } \\
& \text { وسيد قطب في (في ظلال القرآن)، ومن المحدثين: ، ومحمد الغزالي في (نخو تفسير موضوعي لسور القرآن الكريم)، } \\
& \text { وأمين الخولي في (من هَدْي القرآن). }
\end{aligned}
$$

' It is traditional in the sense that it follows the early exegetes' basic principles of exegesis. In his Nazm theory, Islahi follows the six basic principles early exegetes use in interpreting Quran mainly: the Quran itself, sunnah muwatirah (authoritative interpretation of Quran), Hadith, asbab an-nzul munasabah, previous scriptures manily the Bible and Torah, and ancient Arab history and literature. Knowledge of pre- Islamic Arabic grammar and idiom is essential to the correct interpretation of Quran.

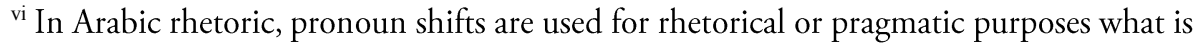
known as iltifat. For more explanation see El-Awa (2006:53) and M. A. S. AbdelHaleem, 'Grammatical shift for rhetorical purposes: iltifat and related features in the Qur'an', Bulletin of the School of Oriental and African Studies, 1992, 55(3): 420.

vii See Sanders and Pander Maat (2006) \& Reckheit, Gert Habel \& Christopher (2011) for an overview of the main approaches to the study of coherence Research in Text Theory: Focus and Coherence in Text Processing.

viii This is known in the Islamic tradition as the science of interpretation " علم التأويل" and there are a lot of well-defined constraints that govern the process of interpretation. See for example "التكميل في أصول التأويل” by Imam Hamiddin Al Farahy.

ix Compare Farahi- Islahi's concept of 'amud' "the unifying theme that connects the different topics within the surah together and sometimes helps connect surahs as well".

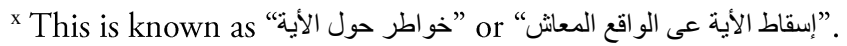


${ }^{x i}$ It is a common practice of early exegetes to cite verses of pre-Islamic poetry and compare the content to certain verses or as evidence of the meaning of a certain vocabulary item used in the surah. For example, the word "thajajja" in pre-Islamic Arabic to mean "pouring" or "pouring rain" in verse 14.

xii For the full text and its translation see the appendix or follow the link http://www.quran4u.com/Tafsir\%20Ibn\%20Kathir/078\%20Naba.htm 